es langfristig befördert werden kann, also welche konkreten Grenzen oder Anreize von den politischen Entscheidungsträgern als Leitplanken für die Ausrichtung von Wachstumsprozessen gesetzt werden.

Aber selbst eine Versachlichung der Diskussion wird nicht vermeiden können, dass dieses politisch so wichtige Thema am Ende auch politisch behandelt werden wird. Die EnqueteKommission „Wachstum, Wohlstand, Lebensqualität - Wege zu nachhaltigem Wirtschaften und gesellschaftlichem Fortschritt in der Sozialen Marktwirtschaft" des Deutschen Bundestags ist in jedem Fall das richtige Forum, um den Brückenschlag zwischen Wissenschaft und Politik zu diesem Thema zu versuchen. Ob der Versuch gelingt, wird sich zeigen. Jetzt ist die Kommission in ihrer Gesamtheit in der Bringschuld.

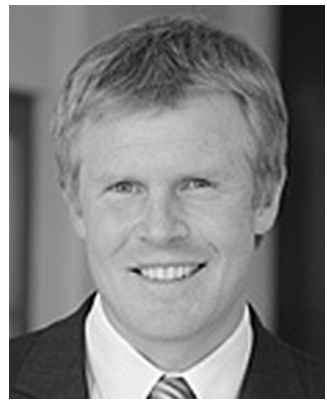

Henrik Enderlein ist Professor für politische Ökonomie und Vizedekan an der Hertie School of Governance. Er ist Mitglied der Enquete-Kommission „Wachstum, Wohlstand, Lebensqualität - Wege zu nachhaltigem Wirtschaften und gesellschaftlichem Fortschritt in der Sozialen Marktwirtschaft" des Deutschen Bundestags, Email: enderlein@hertie-school.org

\title{
Literatur
}

Wolfgang Ismayer (1996). Enquete-Kommissionen des Deutschen Bundestags. In Aus Politik und Zeitgeschichte 27/1996.

\section{Public Administration: Underperforming or Underanalyzed?}

\author{
Mark T. Fliegauf
}

\begin{abstract}
Kernaussagen
Conventional wisdom presumes that public administration lags behind private organizations in both effectiveness and efficiency. Several causal mechanisms for this underperformance have been advanced, including the sourcing of its workforce, the lack of competitive pressures and its ineffectual organizational design. Perhaps the most compelling causal pathway points to an innovation deficit for civil service's comparative disadvantage. Yet, the public sector reforms under New Public Management may seriously hinder rather than improve public administration's long-term efficiency by eliminating innovation capacities. Due to the dearth of comprehensive, large-scale analyses, however, the verdict that public sector bureaucracies are underperforming must be taken with caution.
\end{abstract}

\section{The Efficiency Divide: Myth or Reality?}

According to conventional wisdom, public administration ${ }^{1}$ underperforms. Whereas private organizations are regarded as lean, productive and well-oiled machines, the public sector is perceived as bloated, sluggish and inefficient. Thus, it is not surprising that trust in German civil service hovers around a mere 50 percent, barely exceeding that in political institutions like Parliament (see Rölle, 2009, p. 231). Yet effectiveness and efficiency constitute important normative goals of democratic governance and embody the core principles of New Public Management (NPM) reforms, which have been widely adopted by OECD countries since the 1980 s and 1990 s. Guido Bertucci, Director of the Division for Public Economics and Public Administration of the United Nations, recently emphasized that "redesigning the State for the tasks of the $21^{\text {st }}$ century does not imply 'big government' but rather stress on competence and quality of performance in the discharge of functions, which represent the core of the responsibilities of modern states" (quoted in Kamarck, 2003, p. 2).

The following paragraphs will examine the main theoretical arguments supporting the notion that public administration underperforms and stands at a comparative disadvantage to the private sector. Operating at different levels of analysis, the arguments point to qualitative differences in the workforce (individual level), inadequate competitive pressures (system level) and excessive departmentalization and inertia (organizational level). The most convincing argument combines elements from all three as it highlights a lack of innovative ability within public services. In this regard NPM programs might surprisingly hinder rather than improve organizational performance of the civil service.

1 I use the terms „public services“, „civil service“, “public sector” and „public administration“ interchangeably. 


\section{Human Capital: Sourcing}

As with all organizations, public administrations are driven by its people. Thus, it is reasonable to question whether the public sector sources a qualitatively different workforce than the private sector.

John Donahue (2008) has shown that the pay structures of the public and private sectors in the United States have increasingly diverged during the last three decades. While public employees fare better at the lower end of the occupational ladder, high-ranking public employees receive significantly less salary than their private counterparts. Based on this pay gap and anecdotal evidence, he infers that "the best and the brightest" individuals prefer to seek employment in the private field, leaving public administration with more complacent and less talented managers.

However, Donahue provides only scant and incomprehensive evidence for his reasoning. He overlooks that financial incentives are only one, albeit an important, consideration for employment seekers. Risk averse individuals, for example, may value different benefits in public sector employment. None other than Herbert Simon (1998) alluded to this fact when he stressed that people have diverse motives and priorities, including identification and loyalty, which may outweigh financial self-interest when choosing career paths.

\section{Monopoly Provider: Managerial Slack}

In contrast to most private organizations, public administration operates in a rather privileged position as the monopoly provider of goods and services. According to the neoclassical model of economics, this blessing is simultaneously a curse as the lack of competitive pressures incentivizes managerial slack, that is a decrease in workforce diligence which results in inefficiencies (Stiglitz \& Walsh, 2006, p. 291). Thus, some scholars have advocated the introduction of agency competition in the public sector to enhance effectiveness (Osborne $\&$ Gaebler, 1992).

Wilson (1989), on the other hand, has warned against the introduction of functional rivals in civil services as the concerns for bureau maintenance may override any potential benefits from inter-agency competition. In one of the few studies conducted in this regard, Krause \& Douglas (2006) found that the introduction of the Congressional Budget Office in 1975 did not lead to improvements in the quality of fiscal projections, a task initially performed solely by the U.S. Office of Management and Budget, whose performance only deteriorated with the establishment of the rival agency.

\section{Departmentalization: Structural Holes \& Inertia}

Although departmentalization is inevitable in all modern organizations, whether public or private, the public sector is often characterized by an extraordinarily high degree of departmentalization, mostly along the lines of services or policy areas. ${ }^{2}$ Nevertheless, policy and administrative pro- blems in an increasingly complex and interdependent world create the need for civil services to coordinate, to exchange information and to solve problems across departmental boundaries. The prominent absence of cross-departmental teams and networks in large parts of public administration impedes government bureaucracies from tiding over "structural holes" (Burt, 2004, 2005) and from merging complementary yet divided information flows.

While overcoming inertia presents a challenge to all organizations (Hannan \& Freeman, 1984), public bureaucracies might exhibit higher degrees as they do not face impetus to change. Even the most change resistant employee is usually willing to accept a new set of organizational structures and to end turf battles when he perceives the future of the company at risk and thus his continuous employment threatened. However, Kelman (2005 b) shows in his analysis of procurement reform in the U. S. administration that the view of a department or administration as unitary actor is grossly reductionist. He found a "change vanguard" of individuals dissatisfied with the status quo throughout the public services who were willing to overcome inertia and forge "reform coalitions" with co-workers.

\section{Innovation: Pressures \& Experimentation}

An evolutionary perspective of economics and organizational theory upholds innovation ${ }^{3}$ as the key driver of organizational transformation, and in turn efficiency. Private corporations constantly balance between "flexibility and stability" (McKelvey $\&$ Holmen, 2006) to carve out comparative advantages in competitive environments. Without adequate competitive pressures, public administrations lack innovation, rendering them inefficient compared to their private counterparts.

Potts (2009) is only the latest analyst to detect an innovation deficit in public organizations. Interestingly, he argues that the story is more complex and attributes a substantial degree of civil service's innovation deficit to NPM's focus on efficiency and financial accountability. Since innovation is the result of experimentation in the face of uncertainty, by nature it bears a necessary degree of inefficiency. Although financial resources are wasted during the innovation process, the end result is a long-term, efficiency-enhancing "winner". Yet NPM's narrow focus on efficiency aims at eliminating any form of waste, thereby also strangulating financial resources for policy and organizational experimentation.

\section{Public Administration: Underperforming or Under- Analyzed?}

Given the spatial constraints of this entry, the above discussion is rudimentary, and much remains to be expressed on this

2 Departmentalization occurs along job function, products (or services) or geography (Huczynski \& Buchanan, 2007, pp. 462-3).

3 Innovation is defined as the "generation, acceptance, and implementation of new ideas, processes, products, or services" (Kanter 1985, S. 20). 
topic. Yet, three preliminary conclusions can be drawn: First, theoretical arguments pinning the public sector's alleged underperformance to workforce quality, to inadequate competition or to departmentalization and structural inertia are met with empirical or theoretical challenges. Second, public administration does seem to face a significant innovation deficit which constrains its performance in both relative and absolute terms. NPM's focus on waste reduction further exacerbates this problem by withholding necessary financial resources for experimentation. Thus, the drive for more efficiency, which lies at the heart of the NPM paradigm, might actually prove to be counterproductive in the long run.

Last, much of the research on public services and their performance remains guesswork given the absence of large scale empirical analyses. Accordingly, the notion that public administration is underperforming compared to the private sector remains more popular myth than academically grounded "reality". Amirkhanyan, Kim \& Lambright (2008), for example, found in a panel analysis of private and public nursing care homes in the United States that the latter significantly outperformed the former in terms of quality. Given that "the field of organization studies has grown enormously over the last decades" while "the attention the field pays to public organizations and public policy problems has withered" (Kelman 2005 a, p. 967), we should withhold judgment on whether public administration actually underperforms. We can say with confidence, however, that it is severely underanalyzed.

\section{Bibliography:}

Amirkhanyan, A. A., Kim, H. J., Lambright, K. T. (2008). Does the Public Sector Outperform the Nonprofit and For-Profit Sectors? Evidence from a National Panel Study on Nursing Home Quality and Access. Journal of Policy Analysis and Management, 27(2), 326-353.

Burt, R. S. (2004). Structural Holes and Good Ideas. American Journal of Sociology, 110, 349-399.

Burt, R. S. (2005). Brokerage and Closure. An Introduction to Social Capital. Oxford: Oxford University Press.

Donahue, J. D. (2008). The Warping of Government Work. Cambridge: Harvard University Press.

Hannan, M. T., \& Freeman, J. (1984). Structural Inertia and Organizational Change, American Sociological Review, 49, 149-164.
Huczynski, A., \& Buchanan, D. (2007). Organizational Behaviour: An Introductory Text. $6^{\text {th }}$ Edition. Harlow: Prentice Hall/Financial Times.

Kamarck, E. C. (2003). Government Innovation Around the World. Cambridge: Ash Institute for Democratic Governance and Innovation, John F. Kennedy School of Government, Harvard University, November 2003.

Kanter, R. M. (1985). The Change Masters: Corporate Entrepreneurs at Work. London: Unwin.

Kelman, S. (2005 a). Public Management Needs Help! Academy of Management, 48(6), 967-969.

Kelman, S. (2005 b). Unleashing Change. A Study of Organizational Renewal in Government. Washington, DC: Brookings Institution Press.

Krause, G. A., \& Douglas, J. W. (2006). Does Agency Competition Improve the Quality of Policy Analysis? Evidence from OMB and $\mathrm{CBO}$ Current Year Fiscal Projections. Journal of Policy Analysis and Management, 25(1), 53-74.

McKelvey, M., \& Holmen, M. (Hrsg.) (2006). Flexibility and Stability in the Innovating Economy. Oxford: Oxford University Press.

Osborne, D., \& Gaebler, T. (1992) Reinventing Government: How The Entrepreneurial Spirit Is Transforming The Public Sector. Reading: Addison-Wesley.

Potts, J. (2009). The Innovation Deficit in Public Services: The Curious Problem of Too Much Efficiency and Not Enough Waste and Failure. Innovation: Management Policy and Practice, 11(1), 34-43.

Rölle, D. (2009) Vertrauen in die öffentliche Verwaltung - Zwischen Systemstabilität und Modernisierungsdruck. Der moderne Staat, 2(1), 219-242.

Simon, H. A. (1998). Why Public Administration? Journal of Public Administration Research and Theory, 8(1), 1-11.

Stiglitz, J. E., \& Walsh, C. E. (2006) Principles of Microeconomics. 4th Edition. New York: W. W. Norton.

Wilson, J. Q. (1989). Bureaucracy: What Government Agencies Do and Why They Do It. New York: Penguin Books.

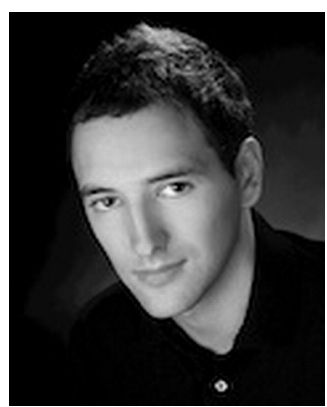

Mark T. Fliegauf lehrt Führung am Geschwister-Scholl-Institut der LMU München und ist derzeit Academic Visitor am Department of Economics der University of Oxford. Er hat Politikwissenschaften (M.A.) in München, Tokio und Harvard studiert und Beiträge zu politischer Führung in Zeitschrift für Politikwissenschaft und Aus Politik und Zeitgeschichte veröffentlicht. E-Mail: mtf33@cam.ac.uk

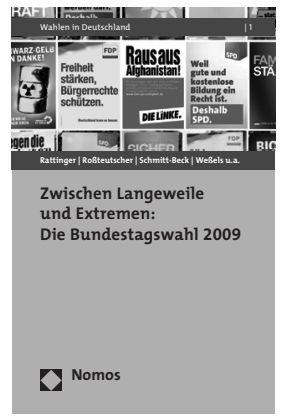

Zwischen Langeweile und Extremen: Die Bundestagswahl 2009

Von Hans Rattinger, Sigrid Roßteutscher, Rüdiger Schmitt-Beck und Bernhard Weßels und Ina Bieber, Jan Eric Blumenstiel, Evelyn Bytzek, Thorsten Faas, Sascha Huber, Mona Krewel, Jürgen Maier, Tatjana Rudi, Philipp Scherer, Markus Steinbrecher, Aiko Wagner und Ansgar Wolsing 2011, 300 S., brosch., 19,90 €, ISBN 978-3-8329-5889-3

(Wahlen in Deutschland, $B d .1$ ) nomos-shop.de/12813

Bitte bestellen Sie im Buchhandel oder versandkostenfrei unter $\downarrow$ www.nomos-shop.de

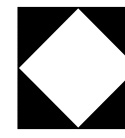

